\title{
Development of Hodgkin Lymphoma in a Patient with Common Variable Immunodeficiency
}

\author{
Yaygın Değişken İmmün Yetmezlikli Hastada Hodgkin Lenfoma Gelişimi
}

\begin{abstract}
(1)
Keywords: Common variable immunodeficiency, Hodgkin disease, lymphoma

Common variable immunodeficiency (CVID) is a primary immunodeficiency, which is characterized by insufficiency in the synthesis of immunoglobulins due to the disruption of B cell differentiation. The term "variable" in its name describes the heterogeneous clinical picture (infections, chronic lung disease, autoimmune diseases, gastrointestinal disorders, and malignancy) in this disease. Although the risk of developing malignancy in children with primary immunodeficiency is reported to be $4 \%$, this rate is 10.000 times higher than healthy subjects of similar age. Non-Hodgkin lymphoma (NHL) accounts for $60 \%$ of malignancy in primary immunodeficiency patients (1). In the cohorts, the incidence of cancer in CVID patients was 15-21\%. The most common malignancy was reported to be NHL, followed by gastric, breast, bladder, and cervix tumors (2-4). Our case shows that Hodgkin lymphoma may rarely develop in CVID and is presented to raise awareness.
\end{abstract}

\author{
(1) Öner Özdemir ${ }^{1}$, (1) Mehmet Fatih Orhan², (1) Gizem Böke Koçer ${ }^{3}$, (1) Mustafa Büyükavc12 \\ 1Sakarya University Training and Reaearch Hospital, Clinic of Pediatrics, Division of Allergy and Immunology, Sakarya, Turkey \\ 2Sakarya University Training and Research Hospital, Clinic of Pediatrics, Division of Hematology and Oncology, Sakarya, Turkey \\ 3Sakarya University Training and Research Hospital, Clinic of Pediatrics, Sakarya, Turkey
}

Anahtar Kelimeler: Yaygın değişken immün yetmezlik, Hodgkin hastalı̆̆ı, lenfoma
Our 9-year-old patient had severe mental retardation and optic atrophy complications due to convulsion lasting 20 minutes on postnatal $35^{\text {th }}$ day. He had used antiepileptic (carbamazepine) treatment that was started at the age of 5 months with the diagnosis of epilepsy for three years. Laboratory tests requested for frequent bronchitis (five per year), otitis (thirteen per year) and antibiotic use (each month) revealed hypogammaglobulinemia with immunoglobulin G (IgG): $365 \mathrm{mg} /$ $\mathrm{dL}, \mathrm{IgA}:<26 \mathrm{mg} / \mathrm{dL}$, and $\mathrm{IgM}:<18 \mathrm{mg} / \mathrm{dL}$. Lymphocyte subsets were normal. Anti-Rubella IgG was $19 \mathrm{U} / \mathrm{mL}$, and anti-HBs was $148 \mathrm{mIU} / \mathrm{mL}$ in response to previous vaccines. Isohemagglutinin antibody was negative, and anti-HAV IgG $(11.3 \mathrm{U} / \mathrm{mL})$ and anti-CMV $\operatorname{lgG}(1 \mathrm{U} / \mathrm{mL})$ titers against previous infections were weak positive. Fine needle aspiration biopsy of $3 \times 4 \mathrm{~cm}$ lymphadenopathy (LAP) in the left cervical region, which was detected during intravenous immunoglobulin administration for the third time with the diagnosis of CVID, revealed abundant lymphoid cells, immunoblasts and Reed-Stenberg cells with distinct nuclei, some with single, some with more than one nucleus. Abdominal ultrasonography was normal. Neck ultrasonography showed a large number of pathological LAPs in the left jugular chain and supraclavicular region, with the largest being $32 \mathrm{~mm}$ in diameter in the left jugulodigastric region. Positron emission tomography/computed tomography revealed hypermetabolic LAPs in the left upper lower jugular and supraclavicular space in the left side of the neck (Figure $1 \mathrm{a}, \mathrm{b}$ ), slightly increased uptake in the spleen parenchyma, and diffuse hypermetabolic appearance at the bone marrow, suggesting lymphoproliferative malignancy. Excisional biopsy specimens were positive for CD30/CD15, and Fascin staining (compatible with nodular sclerosis type), and the patient was diagnosed as Hodgkin lymphoma. EBV test by polymerase chain reaction was negative. (The patient's consent was obtained for presentation).

Despite the risk of toxicity, routine chemotherapy provided survival in $80 \%$ of patients with NHL. It has been proposed to reduce the dose of treatment, but survival in standard chemotherapy patients is reported to be better than in those receiving low-dose chemotherapy $(1,5)$. In our case, Hodgkin lymphoma (stage $3 \mathrm{~A}$ ) was diagnosed five months after the diagnosis of CVID, and a reduced dose of ABVD (Adriamycin, Bleomycin, Vinblastin, Dacarbazine) was decided.

It should be known that the risk of malignancy is increased in CVID, and the physical examination should be performed in routine hospitalizations, and especially LAP should be considered. This will provide the patient with early diagnosis and treatment. 
a

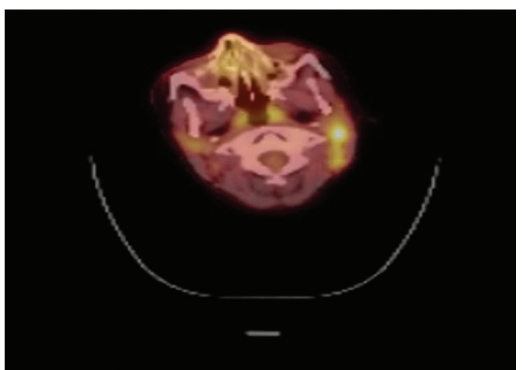

b

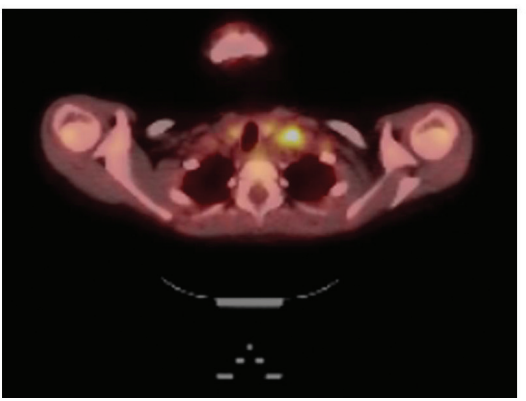

Figure 1. a,b) In the positron emission tomography/computed tomography report of our patient, mild hypermetabolic lymphadenopathy with conglomerate is observed on the left side of the neck (jugulo-digastric and supraclavicular lymph nodes)

Informed Consent: The patient's consent was obtained for presentation.

Peer-review: Internally peer-reviewed.
Author Contributions: Surgical and Medical Practices - Ö.Ö., M.F.O. G.B.K., M.B.; Concept - Ö.Ö., M.F.O., G.B.K., M.B.; Design - Ö.Ö., M.F.O., G.B.K., M.B.; Data Collection and/or Processing - Ö.Ö., M.F.O.; Analysis and/or Interpretation - Ö.Ö., M.F.O., G.B.K., M.B.; Literature Search Ö.Ö., M.F.O.; Writing Manuscript - Ö.Ö., M.F.O., G.B.K., M.B.

Conflict of Interest: No conflict of interest was declared by the authors.

Financial Disclosure: The authors declared that this study received no financial support.

\section{References}

1. Emir S, Vezir E, Azkur D. Characteristics of children with non-Hodgkin lymphoma associated with primary immune deficiency diseases: Descriptions of five patients. Pediatr Hematol Oncol 2013; 30: 544-53.

2. Vajdic CM, Mao L, van Leeuwen MT, Kirkpatrick P, Grulich AE, Riminton S. Are antibody deficiency disorders associated witha narrower range of cancers than other forms of immunodeficiency? Blood 2010; 116: 1228-34.

3. Resnick ES, Moshier EL, Godbold JH, Cunningham-Rundles C. Morbidity and mortality in common variable immune deficiency over 4 decades. Blood 2012; 119: 1650-7.

4. Tak Manesh A, Azizi G, Heydari A, Kiaee F, Shaghaghi M, Hossein-Khannazer N, et al. Epidemiology and pathophysiology of malignancy in common variable immunodeficiency? Allergol Immunopathol (Madr) 2017; 45: 602-15.

5. Seidemann K, Tiemann M, Henze G, Sauerbrey A, Müller S, Reiter A. Therapy for non-Hodgkin lymphoma in children with primary immunodeficiency: Analysis of 19 patients from the BFM Trials. Med Pediatr Oncol 1999; 33: 53644. 